Medicine Updates

Faculty of medicine

April 2021,volume 5, issue 5 https://muj.journals.ekb.eg

dean@med.psu.edu.eg

vice_dean_postgraduate@med.psu.edu.eg

DOI: $10.21608 / \mathrm{muj} .2021 .61475 .1041$

Submitted: $4 / 2 / 2021$

Accepted : 15/2/2021

Pages:31- 59

\title{
"Implementation of Fire Safety Using Quality Protocols in Port Said Private Hospital"
}

Dr. / Adel Mohamed El Shafey

General Director of AL Soliman Hospital, Consultant of OBS/GYNE

Dr. / Lamis Amr Adel Ali Mahmoud

Dermatology Resident, Universal Health Insurance, Egyptian Ministry of Health.

Mrs. / Rana Salah EL Zeney

Director of Chairman's office, AL Soliman Hospital Port Said

Dr./Amany Yahya Abo Bkr

Family Medicine Resident, Omar Bin Al-Khattab Medical Center, Universal Health Insurance.

Dr. / Ahmad Momdouh Mohamed Idris

Pharmacist, Quality specialist, Al Soliman Hospital

Dr./ Toka Kamal Ghoniem.

Pharmacist, El Nasr Specialized Hospital.

Dr. / Hady Khaled Osman El-Beliessy

Dentist, Omar Bin Al-Khattab Medical Center 


\section{ABSTRACT}

Background: The most important necessity in any hospital is that it does not cause any harm to the patient. In order to achieve this, hospital management needs to envision a specific set of standards and regulate them to function and they must not deviate from the safety standards envisioned by the administrative bodies. Starting from building of the hospitals to their operating system, many procedures must be followed to avoid risks specifically fire. Hospitals contain a variety of substances that can contribute to fire events.

Aim of the studv: Implementation a complete firefighting and alarm system for the hospital to make a safe with no fire hospital.

Methodologv: To identify the need for this project, the following methods are going to be done:

First: five stages of 6 sigma approach: Define: study and understand how to protect hospital against fier by using the Egyptian code. Measure: develop process map, conduct time study. Analyze: the collected data and statistical analysis Improve: identify potential causes of delay. Control: recommendation and improvement using managerial process of analysis.

Second: SWOT, TWOS, ETOP.

Third: Fish-bone diagram.

Conclusion: It can be concluded that hospital management has a prime responsibility toward safety of patients by implementing control measures to fire accidents. Impact of fire could be reduced with proper and ideal safety management in hospital building. Every single employee of a hospital shall follow her/his responsibility during fire emergencies and try to save as many potential victims as possible without waiting for instructions.

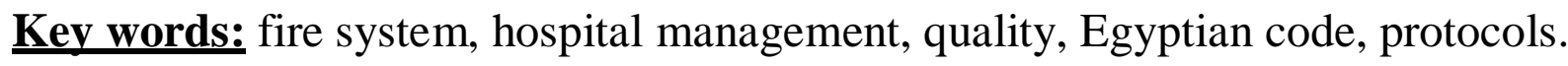




\section{INTRODUCTION}

The most important necessity in any hospital is that it does not cause any harm to the patient. In order to achieve this, hospital management needs to envision a specific set of standards and regulate them to function and they must not deviate from the safety standards envisioned by the administrative bodies. Starting from building of the hospitals to their operating system, many procedures must be followed to avoid risks specifically fire. Hospitals contain a variety of substances that can

contribute to fire events. Also, people inside the hospital have different physical and mental characteristics that have different reactions to them. Looking at the general population inside the hospital, it constitutes continuous treatment for patients under supervision. While some patients can rationalize a situation; there are some patients who cannot (1). Evacuation during fire accidents becomes difficult for these patients. In the past, it has been witnessed that hospitals are susceptible to fire hazards and are proven to have tedious evacuations with high fatalities. Effective safety management system requires implementation of meticulously planned logistics and readiness in case of an emergency Boyd (2). The Past accidents in hospitals are poorly reflected in the implementation of appropriate safety protocols and an inadequate emergency response. Safety must be a value in the organization's mind.

\section{Ebidemiology}

- There were numerous serious historical fire accidents in the hospitals . These accidents can be caused by different ways. The eight leading causes of hospital fires in the United States of America are shown in the chart below (these figures are based on data from the National Fire Protection Association).(3) 


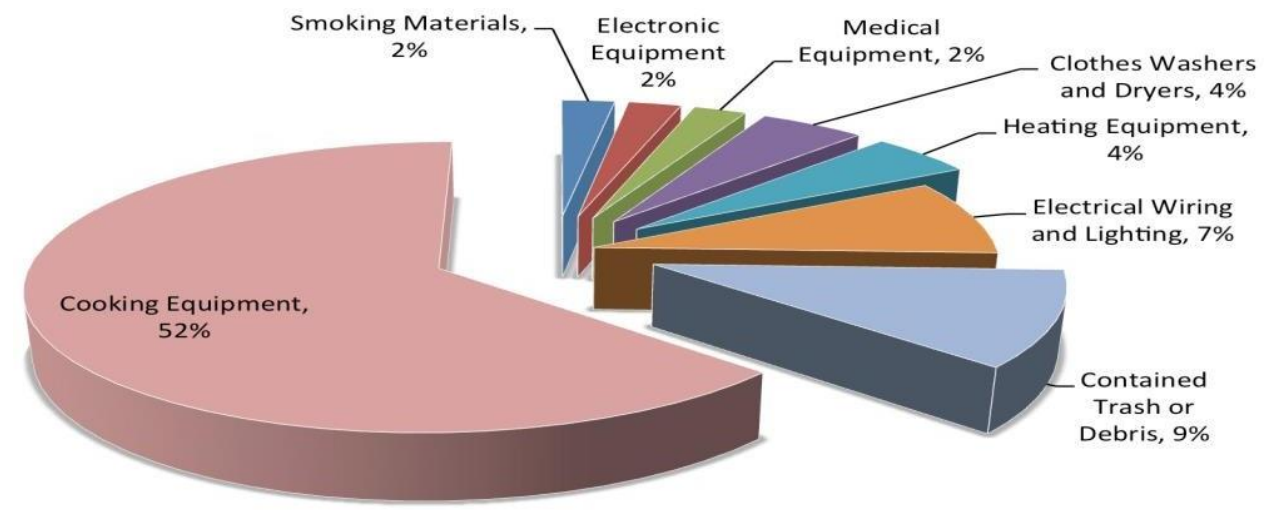

-In these fire accidents, numerous people were killed and injured and valuable property was damaged. The past accidents happened in hospitals reflect poorly on the implementation of proper safety protocols and inadequacy of emergency response.there have been major incidents in hospitals reported in the past, including the fire accident that occurred in AMRI, a hospital located in Kolkata, which killed almost 90 people in the year 2012.(4) It is one of the recent accidents happened in hospitals in India. In the morning of May 15th, 1929 Cleveland hospital in USA encountered a massive fire accident followed by poisonous gas release from burning nitrocellulose X-ray film ignited by a nearby light bulb (5). Around 125 people died in this disaster since there was no proper evacuation strategy and lack of fire protection systems. (6)

- A detailed study on fire incidents of 13 hospital buildings were used ,All the incident cases were constructed on some norms to be designated. For example, one of the norms included higher rate of injuries and casualties. As a result, number of people were killed and injured during fire incidents happened. Also, the hospitals while handling fire accidents have to meet the faults and glitches. In Fig. 1, the blue area denotes three fire accidents before 1950; the red area denotes six fire accidents which occurred between 1950 and 2000; and the green area denotes four accidents chosen after 2000.(7) 

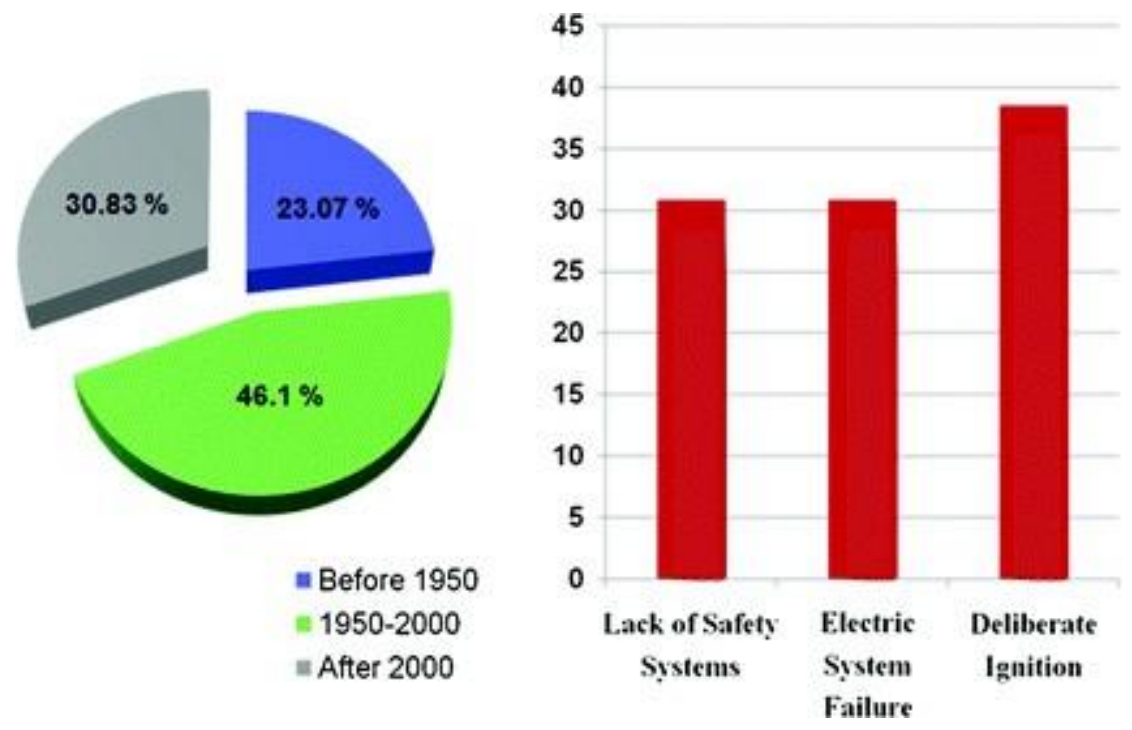

\section{Aim of work}

Implementation a complete firefighting and alarm system for the hospital to make a safe un fire hospital.

\section{Importance of the project and its value}

Safe hospital and environment

Obtaining the Egyptian accreditation and supervision authority

Renewal of hospital license

Obtaining the JCI accreditation

Increase profitability and patient's confidence

Vision: We aspire to be a pioneer in providing excellent health services at the regional level.

Mission: The hospital is committed to providing an integrated health service oh high quality within the reach of every one taking into account the ethics of profession and the health of society and environment using recent technology with continuous medical education . 


\section{Methodology}

\section{To identify the need for this project, the following methods are going to be done:}

\section{First: five stages of 6 sigma approach:}

- Define: study and understand the how to protect hospital against fire by using the Egyptian code

- Measure: develop process map, conduct time study which required three months of study.

- Analyze: the collected data and statistical analysis

- Improve: identify potential causes of delay,

- Control: recommendation and improvement using managerial process of analysis, planning and feedback by developed tactics by meeting, advices, notes, continually gathering information. (8)

\section{Second: SWOT , TWOS , ETOP}

\section{SWOT analysis for the project table (2)}

\begin{tabular}{|c|c|c|}
\hline & Favorable & Unfavorable \\
\hline & Strengths & Weaknesses \\
\hline $\begin{array}{l}\text { Internal } \\
\text { factors }\end{array}$ & $\begin{array}{l}\text { 1)The design of the building gives us a chance } \\
\text { for development. } \\
\text { 3)Location of the hospital in the heart of } \\
\text { governorate with easy transportation to the } \\
\text { hospital. } \\
\text { 4) Presence of emergency department, ICU, } \\
\text { CCU, cardiac laboratory, cardiac outpatient } \\
\text { clinic, operative theater a lot of inpatient beds. } \\
\text { 5)The history and background of hospital gives } \\
\text { confidence to people and facilitate our } \\
\text { marketing. } \\
\text { 8)Extremely strong team with excellent } \\
\text { emergency skills. } \\
\text { 10) Infection control, quality control and patient } \\
\text { safety are applied. } \\
\text { 11) Procedures, polices and medical protocol }\end{array}$ & $\begin{array}{l}\text { 1) Lack of communication. } \\
\text { 2) A high number of staff members are } \\
\text { registries or travelers. } \\
\text { 4) Financial losses. } \\
\text { 5) Staff competencies lake of physician. } \\
\text { 7) Poor advertising and marketing. } \\
\text { 8) The medical services in intensive care unit, } \\
\text { emergency unit not completed by catheter unit. } \\
\text { 9) Increase transferring or discharging } \\
\text { coronary heart patient to other hospitals to } \\
\text { complete treatment by catheter. }\end{array}$ \\
\hline
\end{tabular}




\begin{tabular}{|c|c|c|}
\hline & $\begin{array}{l}\text { are usually updated according to the medical } \\
\text { society and the evidence-based medicine. } \\
\text { 12)Cutting edge equipment with } \\
\text { high level of technology in all our department. } \\
\text { 13)Variety of specialized outpatient clinics. } \\
\text { 14)Presence of computer system program that } \\
\text { links all our departments. } \\
\text { 16)having a contract with many companies. } \\
\text { 17)The first private hospital to obtain } \\
\text { accreditation in the governate. } \\
\text { 18) Breathe in financial support through the } \\
\text { charity. }\end{array}$ & $\begin{array}{l}\text { 11)lack of a clear incentive and bonus } \\
\text { mechanism. }\end{array}$ \\
\hline & Opportunities & Threats \\
\hline $\begin{array}{l}\text { External } \\
\text { factors }\end{array}$ & $\begin{array}{l}\text { 2)Enable to focus on development. } \\
\text { 3)Good media relation } \\
\text { Better care delivery } \\
\text { 4)High number of patients demand our } \\
\text { healthcare } \\
\text { 5)Presence of contracts with many medical } \\
\text { insurance } \\
\text { 6) an accreditation } \\
\text { Provides financial support (charity) } \\
\text { 7) Presence of multiple sources of contracts } \\
\text { 8) Increase the prevalence of cardiac risk factor } \\
\text { and cardiac patients in this area. }\end{array}$ & $\begin{array}{l}\text { 1) Competitor } \\
\text { 2) Regulatory standpoint } \\
\text { Contracts with other hospital and clinics is not } \\
\text { efficient. } \\
\text { 3)Need more contracts with a lot of medical } \\
\text { insurance. } \\
\text { 4)Political and economic instability. } \\
\text { 5)Entering comprehensive health insurance } \\
\text { system. } \\
\text { 6)Wideness of marketing media which need } \\
\text { professional team. } \\
\text { 8) Increase water, electricity and phone costs } \\
\text { 9) increase the level of salaries of stuff }\end{array}$ \\
\hline
\end{tabular}

The strategy to turn the threats and weakness to strength and opportunities (TWOS)

1-Implement a fire fighting and alarm system

2-Increase the contract with other medical centers and clinics to use our medical services.

3-Increase the customers services and decrease the wait time.

4-Complete health care service and decreasing patient complains.

5-Speed in performance and accuracy of results.

6-Consultant and medical staff nursing, assistant medical service providers, housekeeper's security need more training.

7-Varity of medical school from different university 
8-Support the marketing unit by professional staff.

9-Hospital introduce all health care services 24 hours a day, 7 days a week

10-Proper communication with client's patients' governors

11-Look for Clients and patients safety and demands.

12- Attract excellent staff by increase their salaries. (9)

Third: fish-bone diagram: (10)

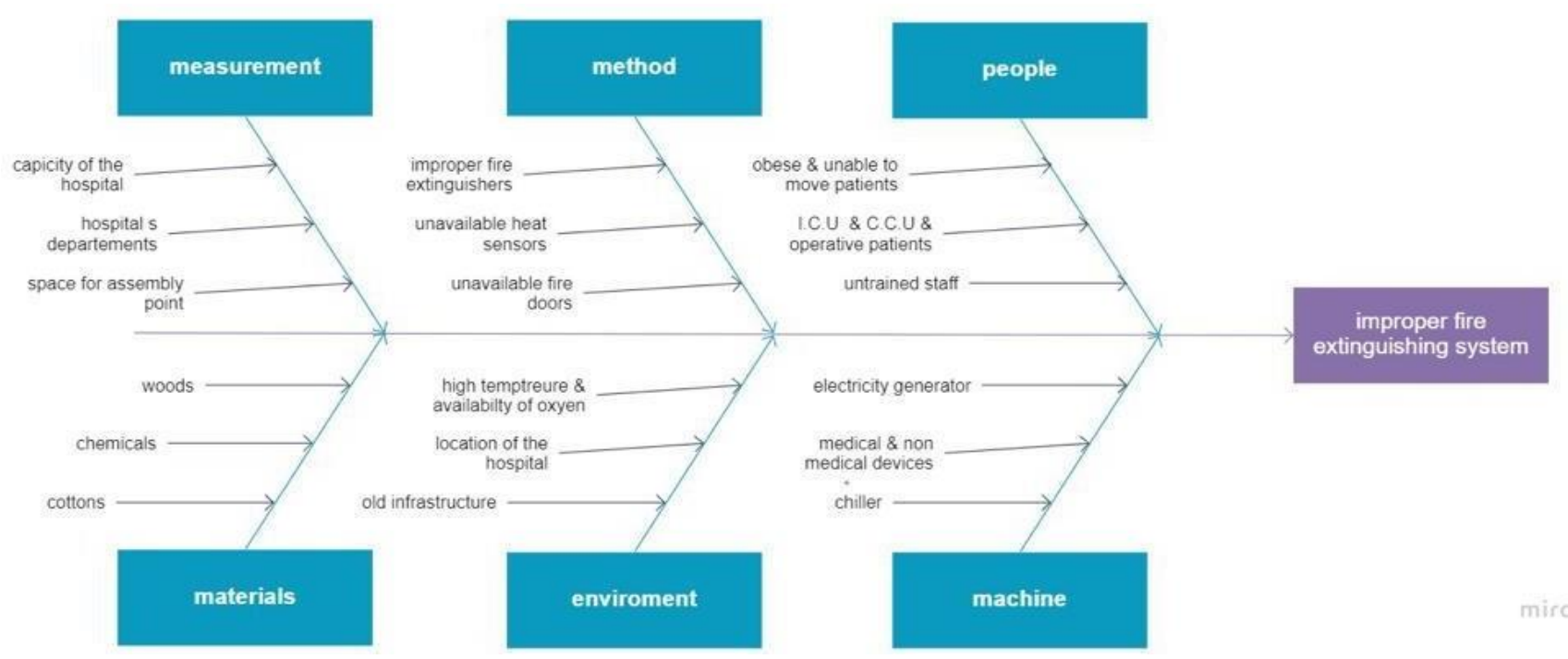

Brainstorming: 3 setting.

First: with the team .

Second: With a consultant team from civil protection authority

Third: With consulting office for feasibility study.

Developing and raising the efficiency of the firefighting and the alarm systems.

Fires are one of the most dangers feared by health care providers, patient, and all hospital workers

It can be extremely frightening patients and hospital staff

In any hospital the possibility of fire can occur due to presence of (oxygen, fuel). 
Evaluation Risk:

Severity: Fatal 5

likelihood likely 4

Score : 20

\begin{tabular}{|l|l|l|l|l|l|}
\hline & $\begin{array}{l}\mathbf{1} \\
\text { Remote }\end{array}$ & $\begin{array}{l}\mathbf{2} \\
\text { Unlikely }\end{array}$ & $\begin{array}{l}\mathbf{3} \\
\text { Possible }\end{array}$ & $\begin{array}{l}\mathbf{4} \\
\text { Likely }\end{array}$ & $\begin{array}{l}\mathbf{5} \\
\text { Certain }\end{array}$ \\
\hline $\mathbf{1}$ & & & & & \\
\hline $\begin{array}{l}\mathbf{2} \\
\text { Minivial }\end{array}$ & & & & & \\
\hline $\mathbf{3}$ & & & & \\
Lost & & & & & \\
\hline $\begin{array}{l}\mathbf{4} \\
\text { Major }\end{array}$ & & & & 20 & \\
\hline $\begin{array}{l}\mathbf{5} \\
\text { Fatal }\end{array}$ & & & & & \\
\hline
\end{tabular}

Risk analysis:

Lilkehood: likely Potential sequence: Extreme

Risk: Very high

\begin{tabular}{|l|l|l|l|l|l|}
\hline & Negligible & Minor & Moderate & Major & Extreme \\
\hline $\begin{array}{l}\text { Almost } \\
\text { Certain }\end{array}$ & & & & & \\
\hline Likely & & & & & Very high \\
\hline Possible & & & & & \\
\hline Unlikely & & & & & \\
\hline Rare & & & & & \\
\hline & & & & & \\
\hline
\end{tabular}

Risk control 
Risk exposure; Major / Expected per control activity : adequate

\begin{tabular}{|l|l|l|l|l|l|}
\hline Major/Expected & & Monitor control & & & \\
\hline Significant/likely & & & & & \\
\hline Moderate/possible & & & & & \\
\hline Minor/unlikely & & & & & \\
\hline Insignificant/Remote & & & & & \\
\hline
\end{tabular}

Excessive Adequate refine need inadequate

Risk Management

Impact /likehood : must manage and monitor risk

\begin{tabular}{|l|l|l|l|}
\hline Significant & & $\begin{array}{l}\text { Must manage } \\
\text { and monitor } \\
\text { risks }\end{array}$ \\
\hline Moderate & & & \\
\hline Minor & & Medium & High \\
\hline & Low & M &
\end{tabular}

Second: escape routes

Third the firefighting system

Fourth: the alarm system and the description of alarm system

Fifthly: extinguishing means by various media

Sixth: ventilation

Seventh electrical connections

Eighth: securing all of the generator rooms, transformer rooms, pump rooms, fuel rooms, cabins, electricity distribution cells

Ninth: indicative signs

Tenth: training on control work 


\section{General description of the hospital}

The address: Port Said and its main façade overlook Saad Zaghloul Street and AlAmin intersection

The owner is a charity

The date issuance of the building permit 1992

Total area 2300meter square

Description of the building : an eight floors building of concrete buildings and components used to provide treatment, surgeries, laboratory, radiology and the works on each floor are as following, administrative offices .

Ground floor 5 rooms for security and reception

, 8 rooms service and maintenance

8 rooms X ray, Sonar and CT scan

5 emergency rooms

Mortuary room, stores, waste rooms, lockers

First floor 26 rooms : 11 administrative offices , 1 lecture hall , 2 rooms server and I 3 rooms laboratory 9 outpatient clinics rooms

Second floor 13 rooms : 2 for one day surgery , 5 operative , 2 laparoscopy , 2 drug and instrument stalk ,2 lockers doctors and nurses

Third floor 21 rooms : renal dialysis 4 rooms , 12 inpatient patients , 2 a break reluctant, 3 administrative offices

Fourth floor 23 rooms: 18 inpatient rooms , 1 a break reluctant, 2 store rooms, 2 administrative offices

Fifth floor critical and intensive care units 24 rooms

Cardiac lab., intensive care unit, outpatient rooms, store rooms pediatric care unit, critical care unit, catheter unit

Sixth floor 10 rooms: 4 stores rooms, cafeteria , 2 adminstrative rooms, water treatment plant 


\section{Seventh floor kitchen}

\section{Escape tracts:}

Escape stairs the hospital is equipped with 2 concrete stairs, one of which $130 \mathrm{~cm}$ wide and the other $110 \mathrm{~cm}$ wide ,more than 210 height suitable for carrying work in buildings and all stairs connected to the ground floor and connected to the exits and drainage outlets of the surrounding streets. All corridors leading to and from the stairs, a width of not less than 2 meters which is appropriate . the number of exit units was calculated according to the work load and the capacity of the exit unit was calculated according to the terms of the code .

Fire zone: the escape route were evaluated according to the Egyptian code, implementation principles and fire requirements

Reach floor of the building is considered a fire zone and it has been designed so that the travel distance does not exceed 20 meters, taking into account that the entire building will be covered by the automatic extinguishing system . Each area has 2 exits on the stairs

All corridors are equipped with an alarm system to address and automatic water extinguishing. All escape routes are provided with phosphorescent signs and arrows to indicate exits and directions. All escape routes are equipped with an artificial lighting system and connected to a generator

source

Electric elevators: There are a total 5 elevators in the hospital, one of them is dedicated to firefighters with a load of more than $900 \mathrm{~kg}$ and connected to the generator as a backup power source that works automatically in the event of a powers outage. All electrical connections to elevators are placed in ducts, and the electrical panel is secured

With an automatic gas extinguishing system $\mathrm{Co} 2$ (fire search)

Dead ends : There are only on the last floor ( archive rooms, and it will be provided by a fire resistant iron escape path that opens directly to the adjacent surface with open fresh air and from it to the main staircase 


\section{General requirements for fire resistance in separators and corridors in}

\section{escaperoutes}

The fire resistance walls of the corridors connected to outside is not less than one hour. Fire resistance of walls of skylights and elevators 2 hours

Fire resistance of walls generally 1-2 hours. Direction of doors toward outside of corridors not inside, of fire resistant material connected by magnetic unit panic

bar .

\section{Evacuation plan}

1- A drawing showing doors windows stairs and corridors

2- Stairs for evacuation

3- The evacuation path is sound, safe, and empty . windows are easy to open

4- Determine the collection diet at the main door of the hospital and make sure everyone is evacuated

5- Telephone number of security, safety, firefighting and civil defense are written

6- The evacuation order is issued by the general manager or his representative

7- Avoid crowding and escape of even floors from the eastern and individual floors from western staircase

8- Evacuation is carried out through the alarm bell

9- Evacuation the building and surrounding obstacles as cars. (11)

\section{During evacuation}

When you listen to the alarm bell.

Close the sources of gases and electricity - leave the area according to your way do not use the elevator and use stairs use the guide boards and arrows to reach the gathering point avoid running and scrambling and report any missing person Evacuation of ICU, CCU and operative patient according to the plan developed in coordination with the nearest hospital taking into account the method of transportation. (12) 
(RACE \& PASS)

RACE (Dealing with fire)

)PASS( How to use

\section{extinguisher)(13) General rules}

Put awet sheet in front of the door to prevent the spread of fire.

Water can be used after switching off the power supply.

Stand upwind, away from fire by 3-5 meters, donnot fight fire from above the flame, move the nozzle of extinguisher left and right and you must know the nearst extingisher and alarm glass breaker.

\section{Firefighting networks and systems}

Asset of pumps dedicated to extinguishing and fighting fire will be installed with a discharge rate of 750 gallons per minute and a manometer lift with a capacity of $75 \mathrm{hp}$, consisting of : Main fire pump with discharge rate $750 \mathrm{~g} / \mathrm{min}, 9$ bar lifter driven by an electric motor $750 \mathrm{hp}$

A backup fire pump with a discharge rate of 750 gallon / min , a bar lift driven by a 4 cylinder diesel engine $75 \mathrm{hp}$, and it works automatically when the power is cut off , the first pump fails or the pressure in network drops

A jockey compensatory pump works to save pressure in the network when opening more than one outlet in the network with a capacity of not less than 5\% of the capacity of the main pump and to stabilize the pressure at 7 bar when opening more than water outlet. (14)

A backup firefighting water tank of poly ethylene connected in a row with each other with a capacity of 90 cubic meters will be installed on the fire line to feed the fire pump group and connect it to the hospital fire network, it is sufficient to operate the system for a period of not less than 30 minutes and is suitable for the degree of danger in the hospital and is connected to the public water network to compensate continuously and withdraw from the tank

A network of fire pipes will be installed in the building consisting of a smooth steam (Cemels). Aschedule of 40, diameter of 6 inches for main entrance to the hospital and through it, a two risers of a diameter of 4 inches are fed table 40 
cemels smooth inside the first to supply 8 fire boxes and it's faucets up to the roof . the second riser supply 7 fire boxes and a sprinkler network, and a controlunit will be installed in each floor to control in the event of maintenance or malfunction in one of the floors. Network drainage rates will be taken into account for the diameters of the pipes to the sprinkler network and fire boxes inall corridors and rooms.

All hospital corridors and rooms will be secured by a total water immersion network, which is an automatic water sprinkler opening at 68 degrees Celsius diameter of $1 / 2$ inch certified and the network of each floor is connected with a control unit connected to the buildings main feeder line for each floor. A 4 inch scimns connection, double sided two socket moss model 2.5 inch outlets morris male will be installed near the main door of the hospital to supply the fire network with water.

all water extinguishing system works automatically when a fire occurs and is able to use for more than 30 minutes and gives a pressure of not less than 5 bar at the farthest point. (15)

\section{The alarm network}

An automatic alarm network will be set up for the entire site and with all its components of the type entitled, provided with a plate placed at the hospital entrance in the camera room to monitor it throughout the day

Heat detectors that work on smoke will be installed, except for the kitchen and the laboratory. A manual alarm system, complete with (bells - key - breaker) will be installed.

All the components are identical to the second part of the Egyptian code.(16)

\section{Extinguishing means by different media}

\section{1-Manual fire extinguishers}

The site is provided with 7 manual fire extinguishing devices that work with dray chemical powder of Bavaria quality, each capacity is $6 \mathrm{~kg}$.

the site will be provided with 8 handheld carbon dioxide fire extinguishers with a capacity of $6 \mathrm{~kg}$ each 
They are all distributed and suspended in walls, corridors, front of escape stairs and at a height of hands reach

\section{2- Fire extinguishing devices for total immersion}

The main transformer room of the building will be insured by supplying it with gas automatic system Co2 (fire search).

The electrical panels in the elevator rooms will be provided with an automatic gas extinguishing system $\mathrm{Co} 2$ (fire search)

\section{3- Wet chemical liquid automatic extinguishing devices}

The hood in the kitchen will be equipped by a wet chemical liquid system that works automatically in the event of fire, god forbid.

Provide a certificate of safety, validity, and efficiency of manual fire extinguishers

\section{Ventilation}

Central air conditioning ducts will be secured by fire dampers

Seventh electrical connections. All electrical connections and wires conform to the loads according to the Egyptian code. All electrical panels are equipped with automatic circuit breakers - it works to cut off the electric current automatically when any shortage occurs in the electrical circuits

\section{Securing places of private nature}

Generator room: with a total immersion system of self extinguishing with carbon dioxide, wall are fire resistant for at least 2 hours, below it sands

The capacity of the generator is $300 \mathrm{k} . \mathrm{v}$ it does not require ozone because it is less than $1000 \mathrm{kv}$

Transformer room: with a total immersion system of self extinguishing withcarbon dioxide

Pump room: extinguishing with automatic water extinguishing system and manual devices

Medical gases chamber will be equipped with automatic water extinguishing system 
Main electrical distributing panels room: automatic switch off with gas filing system $\mathrm{Co} 2$ (fire search) and the sub room with a water immersion system and manual $\mathrm{Co} 2$

Elevator rooms with automatic fire fighting system with Co2 (fire search)

Xray And radiotherapy are secured by automatic extinguishing system with water , taking into account that the pipes are of copper and not iron, as well as the sprinklers as a guarantee that they are not affected or affected by the radiation

Catheter unit: secures by the automatic total immersion system FM200

Paper and archive stores secures by automatic total immersion system FM200 Administrative offices, inpatient rooms, cafeteria, pharmacy, and roads aresecured by automatic sprinklers

The stores do not exceed $180 \mathrm{~cm}$ in height.(17)

\section{Indicative signs}

Phosphorous type, luminous, and arrow direction of security evacuation trends

\section{Training}

On civil protection work on an annual basis with necessary number ( $25 \%)$ of workers in coordination with the civil protection in port said

Training internally about PASS \& RASCE. evacuation drill

\section{Certificates and Documents}

Environment consultant report with a safe waste disposal system

Safety reports compliance and validity of alarm and extinguishing system

Raise the level of insurance against fire hazards according to the requirements of the Egyptian code

Maintenance : contracting with a company for maintenance work Ban of smoking in the building 


\begin{tabular}{|c|c|c|c|c|c|c|c|}
\hline Risk & Goal & Objective & Activities & Team & $\begin{array}{l}\text { Starting } \\
\text { date- } \\
\text { ending } \\
\text { date }\end{array}$ & KPI & Budget \\
\hline $\begin{array}{l}\text { Possibility of } \\
\text { a fire } \\
\text { affecting the } \\
\text { hospital, } \\
\text { patients and } \\
\text { hospital } \\
\text { staff }\end{array}$ & $\begin{array}{l}\text { Protect and } \\
\text { secure the } \\
\text { facility from fire }\end{array}$ & $\begin{array}{l}\text { Insurance of the } \\
\text { facility from fire } \\
\text { risk } \\
\text { Protect patient, } \\
\text { visitors and } \\
\text { workers from fire } \\
\text { hazards } \\
\text { Training of workers } \\
\text { on civil protection } \\
\text { work } \\
\text { Training of workers } \\
\text { on the evacuation } \\
\text { plan } \\
\text { Maintenance } \\
\text { contracts for } \\
\text { firefighting } \\
\text { equipment's and } \\
\text { water tanks }\end{array}$ & $\begin{array}{r}\text { fire works } \\
\text { Sprinikes } \\
\text { Supply, installation and testing } \\
\text { of automatic sprinkles model } \\
\text { SP1 (upright ) amount } 250 \\
\text { automatic sprinkles model SP-2( } \\
\text { pendant ) amount } 150 \\
\text { An automatic sprinkles SP-3 side } \\
\text { wall amount } 150 \\
\text { all NFPA } \\
\text { Piping system } \\
\text { Supply, installation , and testing } \\
\text { of seamless steel pipes schedule } \\
40 \text { as stakes and suspended } \\
\text { ceilings } 25-150 \text { mm in diameter } \\
\text { amount } 4532 \\
\text { Fire hose cabinet } \\
\text { Number, supply, and } \\
\text { Cylinders } 9 \text { kg ,tubes nozzles }\end{array}$ & $\begin{array}{l}\text { Implementatio } \\
\text { n: BG for } \\
\text { engineering and } \\
\text { trading } \\
\text { company } \\
\text { Under super } \\
\text { vision of assaf } \\
\text { consultation } \\
\text { engineering } \\
\text { trade company } \\
\text { Follow up by } \\
\text { our civial } \\
\text { maintenance } \\
\text { department } \\
\text { Training } \\
\text { program } \\
\text { Internal in } \\
\text { charge of safety } \\
\text { occupational } \\
\text { health and } \\
\text { quality } \\
\text { management } \\
\text { External by civil } \\
\text { protection and } \\
\text { civil defense } \\
\text { authority }\end{array}$ & $\begin{array}{l}\text { Project } \\
\text { Start } \\
15 / 1 / 20 \\
21 \\
\text { Finish } \\
15 / 7 / 20 \\
21 \\
\text { Training } \\
\text { Start } \\
1 / 3 / 202 \\
1 \\
\text { Finished } \\
1 / 5 / 202 \\
1\end{array}$ & $\begin{array}{r}\text { Business } \\
\text { \&repaym } \\
\text { ent } \\
\text { payment } \\
\text { Supplying } \\
\text { fire pump } \\
\text { at } \\
30 / 1 / 202 \\
1 \\
\text { Chow } \\
\text { equipmen } \\
\text { ts } \\
\text { End at } \\
1 / 3 / 2021 \\
\text { Installatio } \\
n \text { and } \\
\text { commissi } \\
\text { oning } \\
20 \% \text { per } \\
\text { month } \\
\text { Testing } \\
\text { effectiven } \\
\text { ess } \\
100 \% \text { at } \\
\text { the end of } \\
\text { project }\end{array}$ & 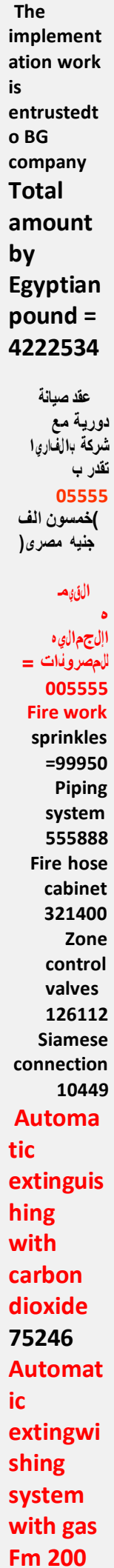 \\
\hline
\end{tabular}


control panel manual shut off

switch and electric wires $\mathbf{3}$ in

number

( servar, UPS catheter, UPS radiotherapy

Fire search

Supply installation and

operation of a fire fighting

system fire search with

acapacity of $2 \mathrm{~kg}$ using $\mathrm{CO} 2$ gas

with length of 4 meter number

Fire fighting pumps

Electrical fire pump

Electric driven fire pump

system consisting of pump, motor, controller it shall be horizontal split case bronze

fitted, double suction centrifugal having design capacity of 750 GPM at a design head of 150 PSIG TDH \& 100 H.P when opening at 2900 RPM (UL listed \& FM approved ) all requirements of NFPA\#20

Diesel fire pump a horizontal centrifugal split case diseal driven fire pumping capacity of $750 \mathrm{GPM}$ at a design head of 150 PSIG TDH \& 100 H.P when operating at 3000 RPM . it shall be UL listed \& FM approved of NFPA\#20 Jocky fire pump design capacity Vertical multi stage of $50 \mathrm{Gpm}$ at head of 160 Psig TDH \&5H.P ( UL listed

fire water tank supply and installation of a polyethylene tank with all its components 15 cubic meters 6

number

emergency fire doors

according to specifications

engineering drawings

fire alarm system 


\section{fire alarm outlet}

a full copper coated $1 * 2 \mathrm{~mm}$ outlet including iron pipe packing and its accessories

fire alarm panel 8 loop addressable type 1 Fire smoke detector 360

number

Fire heat detector 40 number Fire bell 20 number All of UL/FM Fire manual call point 24 in number monitor modules 13 in number Control modules 13 in number

\section{The Legal and Obligatory Study}

\section{The legal study}

A study by the Legal Affairs Department in cooperation with the Medical and Engineering Authority.

Fundamental of project subject to laws governing Arab Republic of Egypt.

Civil protection accreditation for hospital safety conformity.

Occupational safety and health administration

Also, subjected to the standards and policies of the ministry of health and population. Subject to policies, standards and supervision of Egyptian Atomic Energy Authority. (18)

\section{The political study}

Political support for health projects in light of the state's concern for the health of citizens and the providing health service for all 24/7. The political conditions allow the establishment of the project, because political sovereignty currently supports investments and health projects. 


\section{The social study:}

Study the extent of the community's need for the service and the extent of the service's impact on improving the level of health in Port Said. With this project it can be transferred that the availability of the service is not available, it saves effort, money and time, reducing the complications arising from their lack of sufficient availability on port said community. Providing rehabilitation and health education services for the society.

The catastrophic plan:

Management steps:

predicting and diagnosing the crisis determining its cause

Causes analysis and goal setting

Develop an emergency plan

Regular safety Training on the plan

Identifying alternatives reporting system

Continuous improvement

According to Occupational Safety and Health Adminstration Environmental Protecting Agency:

Evacuation plan in the event of a natural disaster.

Evacuation plan in the event of a fire - short circuit.

A plan to deal with power cuts.

Chemical spill handling plan.

A plan for dealing with medical and non-medical waste.

Infection control plan.

Security, safety and fire plans:

\section{Security:}

The hospital has a contract with a trained security company for patient relatives and staff safety.

The presence of a trained and qualified security department. 
Covering the hospital with surveillance cameras.

\section{Safety:}

-We have an occupational health, infection control team for safety and risk management, implementing the civil protection codes. following the infection control guidelines by using the personal protective equipment to prevent hazards such as: corona virus, hepatitis $\mathrm{B}$, hepatitis $\mathrm{C}$ and AID immune deficiency virus. The protective measures is generally required to protect from chemicals, radiation, dust and projectile as face shields, spectacles, apron, masks (surgical \& N95) and goggles.

- Infection control measures in food handling by wearing gloves and masks.

- Preventing and management of chemical hazards by:

1-Protection of health care and patients from chemical hazards

2- safe storage and handling of chemicals

by: labeling and preparation for safety data sheets for chemical hazards.

Risk per hospital admission of dying from a medical error is $>1$ in 1000.

\section{Fire plan:}

Fires can be extremely frightening patients and hospital staff.

The possibility of fire can occur due to presence of oxygen, fuel and heat.

We have our specific fire safety plan in the event of a fire emergency.

A plan to evacuate the hospital (total and partial) by doing four drills per year.

Our goal is preventing and managing of the fire, saving life's minimal loss.

Our quality and safety team are professional and is well-trained on managing fire risks through:

1-Training all stuff in Hospital on risk management plan

2-Providing enough extinguishers

3- well defined evacuation plan

The first way to control accidents and injuries to prevent them following governing agencies standards. Depending on:

Using fire extinguisher (PASS) 
Pull the pin, aim at the base of fire, Squeeze handle, sweep nozzle from side to side standing about $6-10$ feet away from the fire

When fire emergency occurs (RACE)

Rescue, Alarm Contain by closing windows and doors, Evacuate

So, accidents can be divided up to accident related to physical environmental and equipment and accident related to patient care. which in hospital is fire accident, chemical accident, hospital wastes and environmental

So, achieving quality outcomes is a group process.

\section{$\underline{\text { Discussion }}$}

- According to the studied data, few hospitals with high-tech protection systems were not competent enough in fire safety management. Faults and difficulties identified in these fire accidents are as follows:

1. Absence of mechanized firefighting systems.

2. Non-compliance of law enforcement.

3. Myopic planning.

4. Maintenance and management of firefighting appliances.

5. Incompetency of hospital staff regarding safety issues.

6. Combustible materials used and stored in the building.

7. Poor accident management methodology.

8. Legal and administrative bottlenecks regarding security and safety systems.(19)

- One of the primary considerations in preventing hospital fires is to prohibit the use of combustible structural (e.g., floors, walls, roofs, stairwells, fire escapes) and nonstructural (e.g., doors, windows, ceilings, fixtures, façade, insulation, mechanical and electrical conduits) components in the hospital facility.

- New facilities should be designed using building codes and guidelines for fire 
prevention, and the materials used should have adequate fire resistance ratings. (These ratings refer to the duration, usually in hours, that a given material can withstand a fire at a specific maximum temperature before losing its integrity, including its strength and insulation capabilities.) In the case of both structural and nonstructural components, fire resistance ratings/durations can vary from 30 minutes to over 4 hours. (20)

Every hospital building must have at least four emergency exits and a maximum of six (21)

- High rise buildings should be easily reachable by road.(22)

- Equipment operation and maintenance through regular inspection.

Hospital buildings must be inspected in every 6 months, and the inspection process should be filmed.

- As-built drawings or plans for existing facilities are required in order to determine the fire-retardant retrofitting needs of the facility. As-built drawings should also be produced for new facilities for future reference, for example in the case of renovations or refurbishments. These drawings should be submitted to the fire service so that, in the event of an emergency at the medical facility, first responders will have a good knowledge of the layout and location of emergency exits, fire compartments, and so forth, allowing for a more efficient response in saving lives.

- Retrofitting plans for fire prevention (and suppression) should be submitted with an associated price tag for the medical facility's overall operating and maintenance budget. However, the following important questions should be considered: What is the associated "price tag" of a person's life? What is the cost of not providing protection against fires? 


\section{Conclusion}

It's concluded that to address the vulnerability of hospitals to fires, all possible steps should be taken to minimize the hazard of fires in hospitals and to stress the need for evacuation. Hospital Fire Prevention and Evacuation is applicable to existing hospitals that can be retrofitted to improve safety against fires as well as proposed or newly built facilities. The primary aim of a hospital facility is to not evacuate patients unless absolutely necessary. Hence, special attention should be focused on proper prevention and suppression techniques to avoid this worst-case scenario. That being said, evacuation training and preparedness is of paramount importance to avoid and/or minimize loss of life.

\section{$\underline{\text { Recommendations }}$}

It can be recommended that hospital management must have a prime responsibility toward safety of patients by implementing control measures to fire accidents. Impact of fire could be reduced with proper and ideal safety management in hospital building. Every single employee of a hospital shall follow her/his responsibility during fire emergencies and try to save as many potential victims as possible without waiting for instructions.

\section{$\underline{\text { References }}$}

1. chiders, A2010. prioritizing patients for emergency evacuation from emergency evacuation in health from a healthcare facility.

2. A., et al.2014. Emergency planning and management in healthcare: priority research topics. Health systems 3 (2): 83-92.

3. http://www.fiercehealthcare.com/story/eight-leading-causes-hospital-fires/2009$10-20$

4. Nagral, S. 2012. Fire in a hospital. Indian Journal of Medical Ethics 9: 76-77.

5. Gregory, K.L., V.F. Malinoski, and C.R. Sharp. 1969. Cleveland clinic fire survivorshipstudy, 1929-1965. Archives of Environmental Health: An International Journal 18.

6. 508-515. 4. Muchatuta, N.A., and S.M. Sale. 2007. Fires and explosions. Anaesthesia \& Intensive Care Medicine 8 (11): 457-460.

7. Zhu, K., Y. Yang, and Q. Shi. 2016. Study on evacuation of pedestrians from a room with multi- obstaclesconsidering the effect of aisles. Simulation Modelling Practice and Theory 69: 31-42.

8. (Prof. Dr. heba youssef's health quality book chapter 6 ).

9. "SWOT Analysis: Discover New Opportunities, Manage and Eliminate 
Threats". www.mindtools.com.2016. Retrieved 24 February 2018.

10. Ishikawa, Kaoru (1976). Guide to Quality Control. Asian Productivity Organization. ISBN 92-833-1036-5. 
11. Abrahams, John (1994). "Chapter 6: Fire escape in difficult circumstances". In Stollard, Paul; Johnston, Lawrence (eds.). Design against fire: Introduction to Fire Safety Engineering Design. Chapman \& Hall. ISBN 978-0-419-18170-5.

12. U.S. Fire Administration, F.E.M.A., Facts on Fire (2000), http://www.usfa.fema.gov/dhtml/public /facts.cfm.

13. ACTWELL training center, https://www.actwell.com.au/info/news/fire-extinguisheruse

14. Ronchi, Enrico; Nilsson, Daniel (December 2013). "Fire evacuation in high-rise buildings: a review of human behaviour and modelling research" (PDF). Fire Science Reviews. 2 (7): 7. doi:10.1186/2193-0414-2-7.

15. Paulison, R.D.: Working for a Fire Safe America: The United States Fire Administration Challenge (2002), http://www.usfa.fema.gov/dhtml/inside-usfa/about.cfm.

16. Paulison, R.D.: Working for a Fire Safe America: The United States Fire Administration Challenge (2002), http://www.usfa.fema.gov/dhtml/inside-usfa/about.cfm

17. Egyptian Atomic Energy Authority - official website.

18. Zhu, K., Y. Yang, and Q. Shi. 2016. Study on evacuation of pedestrians from a room with multi-obstacles considering the effect of aisles. Simulation Modelling Practice and Theory 69: 31-42.

19. Wabo, N.C., P. Örtenwall, and A. Khorram-Manesh. 2012. Hospital evacuation; planning, assessment, performance and evaluation. Journal of Acute Disease 1 (1): 58-64

20. Bailey, Norman T.J. 1956. Statistics in hospital planning and design. Applied Statistics 5 (3): 146.

21. Hardy, O.B., and L.P. Lammers. 1977. Hospitals, the planning and design process. Aspen Publishers 